\title{
Lung Function and Respiratory Symptoms of Petrol Station Attendants in Central and North Jakarta and Its Contributing Factors
}

\author{
Putri Suci Ramadhany, Faisal Yunus*, Agus Dwi Susanto \\ Department of Pulmonology and Respiratory Medicine Faculty of Medicine Universitas Indonesia, \\ Persahabatan Hospital, Jakarta
}

\section{ABSTRACT}

Background: To satisfy growing needs of petrol consumption in big city many new petrol stations has been built. Petrol station attendant is considered to have high risk exposure to dangerous pollutant from motor vehicle emission and petrol fumes, especially while filling up petrol tanks. Combination of those exhaust and petrol fumes is suspected to cause the reduction of lung function.

Methods: This research is a cross sectional study in petrol station in Central Jakarta and North Jakarta region between August 2017 and February 2018. A total of 97 petrol station attendants were taken in this research using consecutive sampling technique. The subjects were interviewed with questionnaires, spirometry and chest radiograph. Measurements of sulfur dioxide (SO2), nitrogen dioxide (NO2), carbon monoxide (CO), ozone (O3), particulate matter 2,5 (PM 2,5) and steam gasoline (benzene) concentrations were performed at the study sites.

Results: In this study, $56.7 \%$ normal spirometry results, $42.3 \%$ abnormalities in the form of restriction, $1 \%$ obstruction and none of which experienced mixed disorders of restriction and obstruction. Most subjects (84.6\%) did not experience respiratory complaints, $10.3 \%$ had a dry cough and $5.1 \%$ complained of cough with phlegm. There was a statistically significant association between peak expiratory flow and duration of work $(p=0.011)$, but no significant association with other parameters such as forced vital capacity (FVC), \%FVC, forced expiratory volume in the first second $\left(\mathrm{FEV}_{1}\right), \% \mathrm{FEV}_{1}$ and the ratio of $\mathrm{FEV}_{1} / \mathrm{FVC}$.

Conclusion: Prevalence of lung function abnormalities of petrol station attendant is $43,3 \%$ and respiratory symptoms at $15,4 \%$ subject.

Keywords: lung function, petrol station attendant, respiratory symptoms.

*Correspondence: Faisal Yunus - faisalyunus@ymail.com

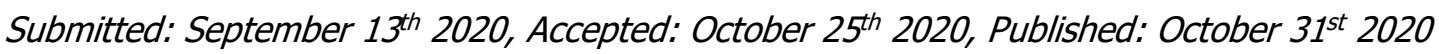




\section{INTRODUCTION}

DKI Jakarta as the capital of the Republic Indonesia which is also the centre of economy and trade recorded as having a crowded population. Based on data from the last Badan Pusat Statistik (BPS) in 2015, there were 10.177.924 inhabitants with a density of 15.367 people per $\mathrm{km} 2$. The large population is accompanied by increased purchasing power, leading to increased ownership of motor vehicles. The number of motor vehicles excluding military, police and diplomatic corps vehicles in Jakarta was recorded as $17,523,967$ vehicles with annual growth of $9.93 \%$ over the last five years. ${ }^{1}$

The increase in the number of motor vehicles contributes importantly to air pollution levels in Jakarta. On a global scale, Jakarta ranks as the thirdworst polluted city in the world after Mexico City and Thailand. ${ }^{2}$ In 2012 it was reported that (particulate matter) in Jakarta had exceeded the threshold to reach $150 \mu \mathrm{g} / \mathrm{m}^{3}$. Government Regulatory No. 41 the Year 1999 about Air Pollution Control states a clean air quality indicator that is when the maximum level of dust particles is 60 $\mu \mathrm{g} / \mathrm{m}^{3} .{ }^{3}$ Environmental statistics in 1994 reported that $91.86 \%$ of air-polluting gas emissions in Jakarta came from the transportation sector. Other sources are from the industrial sector of about $5 \%$, household activity $1.82 \%$ and garbage burning $1.29 \% .^{4}$

Emissions of exhaust gases of motor vehicles contain substances that harm health especially respiratoryhealth such as carbon monoxide ( $\mathrm{CO})$, sulfur dioxide $\left(\mathrm{SO}_{2}\right)$, nitrites dioxide $\left(\mathrm{NO}_{2}\right)$, hydrocarbons $(\mathrm{HC})$ and particulate matter $\left(\mathrm{PM}_{10}\right)$. Data from Ministry of Health in 1999 showed levels of dust, $\mathrm{SO}_{2}$ and $\mathrm{NO}_{2}$ levels in Jakarta, Yogyakarta and Semarang as follows $280 \mu \mathrm{g} / \mathrm{m}^{3}, 0.76$ ppm and $0.50 \mathrm{ppm}$. The figure is already beyond the standard of air quality. ${ }^{4}$ Air Pollution Standard Index in 2003 from 6 monitoring stations in Jakarta showed the maximum daily concentration of $\mathrm{CO}, \mathrm{SO}_{2}$ and $\mathrm{PM}_{10}$ had exceeded the threshold. ${ }^{5}$

General refuelling stations in Indonesia are increasingly established to meet the needs of gasoline motor vehicles increasing. Some workers are tasked to serve the refuelling of motor vehicles with average work for 8 hours per day. Gas station attendant is a profession that has high risk exposed by the harmful pollutants that come from exhaust emissions of motor vehicles and gasoline vapor, especially when charging gasoline. The combination of exposure to vehicle 
exhaust and gasoline vapor is thought to contribute from decreased pulmonary function test. 6,7

In a study conducted by Hulke et al., about pulmonary function test on gas station attendants who have a working period of more than 5 years in the city of Bhopal, India reported that there is a pulmonary function disorder in the form of restrictions on gas station attendants. ${ }^{8}$ Research by Begum et al., in the Indian city of Mysore on gas station workers who worked for more than 2 years also showed restriction disorder. This is seen from a significant decline in $\mathrm{FEV}_{1}$ and FVC with a normal percentage of FEV1s. ${ }^{6}$

Dase et al., in Makasar city, Indonesia showed a decrease in vital lung capacity in 26 gas station attendants out of a total of 46 attendants examined. The decrease in vital capacity of the lungs has a significant relationship with age, working life and smoking habits. ${ }^{9}$ This research will be conducted to find out the pulmonary function and respiratory complaints of gas station attendants in Central Jakarta, North Jakarta and the factors that contribute.

The aimed of this research are obtaining pulmonary function data and respiratory complaints from gas station attendant in Central and North Jakarta, and obtaining data on air quality in the general petrol gas station area of Central and North Jakarta.

\section{METHOD}

This research is a descriptiveanalytic study using a cross-sectional study design. This research was conducted at gas stations in the Central and North Jakarta regions in August 2017 - February 2018. This research population is petrol station attendants who work in the area of Central and North Jakarta. The sample is an affordable population that meets the inclusion criteria. Sampling was taken using consecutive-sampling for each subject who completed the research criteria.

Inclusion criteria are petrol station attendants in Central and North Jakarta with a minimum working period of 1 year; and willing to take part in research and sign an informed consent. Exclusion criteria are petrol station attendants who have a history of pulmonary tuberculosis, suspected pulmonary $\mathrm{TB}$, or are currently on medication; and gas station attendants who already have a history of asthma or COPD before working. Drop out criteria if respondents do not show up for examination or resign as subjects, respondents did not participate in part 
of the planned tests, and respondents did not carry out all tests properly.

\section{RESULT}

This research is a cross-sectional study to find the prevalence of pulmonary function abnormalities and respiratory complaints among petrol stations attendants in Central and North Jakarta and determine the factors that influence it.

There were 97 subjects studied, mostly male. The characteristics of the research subjects, as shown in Table 1 , include age, gender, body mass index, years of work, working hours in a week, wearing masks while working, and smoking habits.

The total research subjects' median age value was 25 years (range 19-42 years), with the proportion of the male sample being more than 72 people (74.2\%). The median Body Mass Index (BMI) in the sample is $22 \mathrm{~kg} / \mathrm{m}^{2}$. It is included in the BMI classification of average body weight according to WHO Asia standards and the Ministry of Health's SKRT standards.

A total of $38.1 \%$ of study subjects did not smoke, and the remaining $61.9 \%$ of subjects smoked, with the most categories being in the mild Brinkman index of $55.7 \%$. Only two subjects $(2.1 \%)$ used masks during work. The median value of working time in the sample was 36 months (range 12-120), and the total working hours in a week was 48 hours (range 40-60 hours).

In this study, normal spirometry results were obtained in 55 study subjects (56.7\%). Table 1 shows that spirometry abnormalities in the form of restriction were most commonly found in 41 subjects $(42.3 \%)$, while one person only experienced obstruction, and none experienced a mixture of restriction and obstruction. Respiratory complaints in the form of dry cough were found in 10 subjects, cough with phlegm in 5 subjects, and no complaints in 82 subjects. There were no complaints of chronic cough and phlegm experienced by the research subjects. The mean spirometry results are shown in Table 1; FVC has a mean of $2868.4 \mathrm{ml}$ with a standard deviation (SB) of $733.74 \mathrm{ml}$ and a mean of percent CVP $81.6 \%$ with SB 15.06. The mean of $\mathrm{FEV}_{1}$ was $2597.4 \mathrm{ml} / \mathrm{second}$ with an SB of $634.99 \mathrm{ml} / \mathrm{second}$, while the mean of $\mathrm{FEV}_{1} / \mathrm{FVC}$ was $90.8 \%$ with an SB of $5.58 \%$. The peak expiratory current (PEFR) has a mean of 6.82 with SB 1.782.

This study found that the proportion of men who had pulmonary function abnormalities was higher than that of women whose spirometry was abnormal. The median age of subjects 
with the abnormal pulmonary function was 26 years. The proportion of nonsmokers was smaller than the group with the mild Brinkman Index (IB). This study did not have subjects with severe IB. All subjects with spirometry disorders in this study did not wear masks when working.

Table 1. Distribution of Subjects According to Characteristics

\begin{tabular}{|c|c|c|}
\hline Variable & Frequency & Mean \pm SD or Median (Min-Max) \\
\hline \multicolumn{3}{|l|}{ Characteristic Subject } \\
\hline Age* & - & $25(19-42)$ \\
\hline \multicolumn{3}{|l|}{ Gender } \\
\hline Male & $72(74,2 \%)$ & - \\
\hline Female & $25(25,8 \%)$ & - \\
\hline Body Mass Index* & - & $22(14-45)$ \\
\hline \multicolumn{3}{|l|}{ The Use of Masks } \\
\hline Yes & $2(2,1 \%)$ & - \\
\hline No & $95(97,9 \%)$ & - \\
\hline Working Period (month)* & - & $36(12-120)$ \\
\hline Length of Work in a Week & - & $48(40-60)$ \\
\hline \multicolumn{3}{|l|}{ Brinkman Index } \\
\hline Nonsmokers (0) & $37(38,1 \%)$ & - \\
\hline Mild smoker (1-200) & $54(55,7 \%)$ & - \\
\hline Moderate smoker (201-600) & $6(6,2 \%)$ & - \\
\hline Heavy smoker (>600) & $0(0,0 \%)$ & - \\
\hline \multicolumn{3}{|l|}{ Test Results } \\
\hline \multicolumn{3}{|l|}{ Spirometry } \\
\hline Normal & $55(56,7 \%)$ & - \\
\hline Obstruction & $1(1,0 \%)$ & - \\
\hline Restriction & $41(42,3 \%)$ & - \\
\hline Mix & $0(0,0 \%)$ & - \\
\hline \multicolumn{3}{|l|}{ Respiratory Complaints } \\
\hline Dry Cough & $10(10,3 \%)$ & - \\
\hline Phlegm Cough & $5(5,1 \%)$ & - \\
\hline No Complaint & $82(84,6 \%)$ & - \\
\hline \multicolumn{3}{|l|}{ Spiro-metric Results } \\
\hline $\mathrm{FVC}(\mathrm{ml})^{*}$ & - & $2868,6 \pm 733,74$ \\
\hline \%FVC* & - & $81,6 \pm 15,06$ \\
\hline $\mathrm{FEV}_{1}(\mathrm{ml})^{*}$ & - & $2597,4 \pm 634,99$ \\
\hline$\% \mathrm{FEV}_{1} *$ & - & $84,1 \pm 14,82$ \\
\hline $\mathrm{FEV}_{1} / \mathrm{FVC}(\%)^{*}$ & - & $90,8 \pm 5,58$ \\
\hline APE* & - & $6,82 \pm 1,782$ \\
\hline
\end{tabular}

Note: $(*)$ Mean \pm standard deviation for normal distribution; median (minimum-maximum) for abnormal distribution 
In the statistical analysis as shown in Table 2, it can be seen that there is no significant relationship between the independent variables consisting of gender, age, Body Mass Index (BMI), $\mathrm{IB}$, use of masks, length of work in months, duration of working hours in a week with spirometry abnormalities after going through statistical testing $(P>0.05)$.

Each spirometry parameter was then analyzed for its relationship to years of service. A significant relationship was obtained between PEFR and working period with a $\mathrm{P}=0.011$, as shown in Table 3. Still, there was no significant relationship between parameters of FVC, \%FVC, $\mathrm{FEV}_{1}$, and $\% \mathrm{FEV}_{1}$ with years of service. There was a tendency for a relationship between the $\mathrm{FEV}_{1} / \mathrm{FVC}$ ratio and tenure but did not exceed the statistical significance limit of 0.05 .

Table 3.Relationship between spometric parameters and working period

\begin{tabular}{lc}
\hline Parameter & P \\
\hline FVC & 0,274 \\
$\% F V C$ & 0,433 \\
$\mathrm{FEV}_{1}$ & 0,384 \\
$\% \mathrm{FEV}_{1}$ & 0,465 \\
$\mathrm{FEV}_{1} / \mathrm{FVC}$ & 0,083 \\
APE* & $0,011 *$ \\
\hline Note: $\mathrm{P}<0,05$ statistically significant
\end{tabular}

Table 2. The relationship between independent variables and spirometric abnormalities

\begin{tabular}{lcccc}
\hline \multicolumn{1}{c}{ Subject Characteristics } & $\begin{array}{c}\text { Abnormal } \\
\text { Spirometric }\end{array}$ & $\begin{array}{c}\text { Normal } \\
\text { Spirometric }\end{array}$ & $\mathbf{P}$ & CI 95\% \\
\hline Gender & 12 & 13 & 0,774 & $0,310-1,9$ \\
$\quad$ Female & 30 & 42 & 0,51 & \\
$\quad$ Male & $26(19-42)$ & $24(19-39)$ & 0,261 \\
Age & $22(14-45)$ & $22(17-41)$ & \\
Body Mass Index & & & \\
Brinkman Index & 18 & 19 & 0,341 \\
$\quad$ Nonsmokers & 23 & 51 & \\
$\quad$ Light smoker & 1 & 0 & \\
$\quad$ Moderate smoker & 0 & 2 & 0,504 \\
$\quad$ Heavy smoker & 0 & 53 & \\
The Use of Masks & 42 & $36(12-108)$ & 0,127 & \\
$\quad$ Yes & $48(18-120)$ & $48(40-60)$ & 0,148 & \\
No & $48(40-60)$ & &
\end{tabular}


Table 4. The relationship between independent variables and respiratory complaints

\begin{tabular}{|c|c|c|c|c|}
\hline \multirow{2}{*}{ Subject Characteristics } & \multicolumn{3}{|c|}{ Respiratory Complaints } & \multirow[b]{2}{*}{$\mathbf{P}$} \\
\hline & No Cough & Dry Cough & Phlegm Cough & \\
\hline Gender & & & & 0,063 \\
\hline Female & 24 & 1 & 0 & \\
\hline Male & 58 & 9 & 5 & \\
\hline Age & & & & 0,487 \\
\hline Body Mass Index & & & & 0,763 \\
\hline Smoking Habit & & & & 0,572 \\
\hline Not a smoker & 33 & 3 & 1 & \\
\hline Former smoker & 3 & 1 & 0 & \\
\hline Active smoker & 46 & 6 & 4 & \\
\hline Brinkman Index & & & & 0,385 \\
\hline Nonsmokers & 33 & 3 & 1 & \\
\hline Mild smoker & 45 & 5 & 4 & \\
\hline Moderate smoker & 4 & 2 & 0 & \\
\hline Heavy smoker & 0 & 0 & 0 & \\
\hline The Use of Masks & & & & 0,544 \\
\hline Yes & 2 & 0 & 0 & \\
\hline No & 80 & 10 & 5 & \\
\hline Working Period (month) & & & & 0,085 \\
\hline Length of Work in a Week & & & & 0,672 \\
\hline
\end{tabular}

This study found that male subjects had more respiratory complaints in dry cough and phlegm than female subjects. However, there was no statistically significant relationship between sex and respiratory complaints. Statistical analysis between the variables of age, BMI, IB, use of masks, length of work in months, and hours of work in a week with respiratory complaints variables also found no statistically significant relationship. The relationship between the demographic independent variable and the respiratory complaint variable is shown in Table 4.
This study involved samples from several gas stations in Central Jakarta and North Jakarta. At the Yos Sudarso gas station, the subjects with lung function abnormalities were five attendants, while the normal ones were 15 attendants. Most of the Pegangsaan gas station attendants showed normal spirometry results, namely 11 subjects, while only 3 subjects had spirometry abnormalities. In contrast to the results obtained at the Pegangsaan gas station, at the Abdul Muis gas station, most gas station attendants had pulmonary function disorders, namely 13 attendants. 
Table 6. Air quality at the study site

\begin{tabular}{lcccccc}
\hline $\begin{array}{c}\text { Gas Station } \\
\text { Location }\end{array}$ & $\begin{array}{c}\mathbf{N O}_{\mathbf{2}} \\
(\leq \mathbf{0 , 2} \mathbf{~ p p m})\end{array}$ & $\begin{array}{c}\mathbf{S O}_{\mathbf{2}} \\
(\leq \mathbf{2} \mathbf{~ p p m})\end{array}$ & $\begin{array}{c}\mathbf{O}_{\mathbf{3}} \\
(\leq \mathbf{0}, \mathbf{1} \mathbf{~ p p m})\end{array}$ & $\begin{array}{c}\mathbf{C O} \\
(\leq \mathbf{2 5} \mathbf{~ p p m})\end{array}$ & $\begin{array}{c}\mathbf{P M 2 . 5} \\
\left(\leq \mathbf{3} \mathbf{~ m g} / \mathbf{m}^{\mathbf{3}}\right)\end{array}$ & $\begin{array}{c}\text { Benzene } \\
(\leq \mathbf{0}, \mathbf{5} \mathbf{~ p m})\end{array}$ \\
\hline Pramuka & $<0,017$ & $<0,022$ & 0,012 & 22 & 0,008 & 0,198 \\
Cikini & 0,019 & $<0,022$ & 0,010 & 20 & 0,014 & 0,144 \\
Abdul Muis & 0,052 & $<0,022$ & 0,009 & 8 & 0,013 & $<0,092$ \\
Yos Sudarso & 0,058 & $<0,022$ & 0,007 & 10 & 0,025 & $<0,092$ \\
Pegangsaan & 0,022 & $<0,022$ & 0,007 & 6 & 0,041 & 0,174 \\
\hline
\end{tabular}

In comparison, the normal ones were only five attendants. At the Cikini gas station, seven attendants showed abnormal spirometry results, and 13 attendants had normal spirometry results, while 14 attendants at Pramuka gas station had spirometry abnormalities and 11 attendants without spirometry disorders. Based on this research, the gas station attendants who experienced the most lung function disorders were at Abdul Muis and Pramuka gas station. These results are shown in Table 5.

Table 5. Distribution of spirometry results based on the gas station location

\begin{tabular}{lcc}
\hline \multicolumn{1}{c}{$\begin{array}{c}\text { Location Gas } \\
\text { Station }\end{array}$} & \multicolumn{2}{c}{ Spirometry Results } \\
\cline { 2 - 3 } & Abnormal & Normal \\
\hline Yos Sudarso & 5 & 15 \\
Pegangsaan & 3 & 11 \\
Pramuka & 14 & 11 \\
Cikini & 7 & 13 \\
AbduL Muis & 13 & 5 \\
\hline
\end{tabular}

This study also measures the air quality, including gas levels of $\mathrm{NO} 2$, $\mathrm{SO}_{2}, \mathrm{O}_{3}, \mathrm{CO}$, and $\mathrm{PM}_{2.5} . \mathrm{NO}_{2}$ gas showed the highest level at the Yos Sudarso gas station (0.058 ppm), but this level was still below the threshold value (TLV), namely $\leq 0.2 \mathrm{ppm}$. $\mathrm{SO}_{2}$ levels at all the gas stations studied showed $<0.022$ ppm, far below TLV ( $\leq 2 \mathrm{ppm}$ ). The highest $\mathrm{O}_{3}$ level at Pramuka gas stations is $0.012 \mathrm{ppm}$, but this level is still below TLV. CO levels at the Pramuka gas station 22 ppm and Cikini 20 ppm showed levels that almost passed TLV ( $\leq 25 \mathrm{ppm}$ ). Benzene levels at all gas stations are still safe, the highest at Pramuka gas stations at 0.198 ppm, while the $\mathrm{PM}_{2.5}$ levels at all research locations were far below TLV. These results are shown in Table 6.

\section{DISCUSSION}

This research was conducted from August 2017 to February 2018, aiming to determine lung function and respiratory complaints and the factors that influence gas station attendants spread across five gas stations in Central Jakarta and North Jakarta. Petrol station attendant who are the research subjects have a working period between 12 to 120 months with 
a median of 36 months and 48 hours of work a week. Only two gas station attendants use masks while working. Complaints of cough were found in 15 attendants (15.5\%) and phlegm in 18 gas station attendants (18.6\%), but these respiratory complaints have not been experienced chronically. Spirometry abnormalities were found mainly in the form of restrictions, namely in 41 attendants (42.3\%), obstruction only in 1 officer (1\%), and none of them experienced mixed restriction and obstruction.

The age characteristics of the study subjects had a median age of 25 years with the youngest age of 19 years and the oldest age of 42 years. The age data in previous research has a normal distribution so that it uses the average age. Research by Zafar in Karachi city, Pakistan has the average age of the study subjects 29.89 years with a standard deviation of 10.72 years. ${ }^{10}$ other studies in Lucknow city, North India showed the average age of similar gas station attendants was 30.6 years with a standard deviation of 11.34 years. ${ }^{11}$ Gender in this study subject was 72 men (74.2\%). This is similar to research conducted by Adeniyi in Nigeria, involving 73 male subjects $(73.7 \%)$ and 26 female subjects $(26.3 \%){ }^{12}$
Nutritional status is assessed based on Body Mass Index (BMI). In this study, abnormal data distribution obtained a median BMI of $22 \mathrm{~kg} / \mathrm{m}^{2}$ with a low value of $14 \mathrm{~kg} / \mathrm{m} 2$ and a top of $45 \mathrm{~kg} / \mathrm{m}^{2}$. Anuja et al., in Chennai city, India found an average BMI of $22.14 \mathrm{~kg} / \mathrm{m} 2$ with a standard deviation of $3.04 \mathrm{~kg} / \mathrm{m} 2$ at gas station attendants who became study subjects. ${ }^{13}$ The average BMI result was similarly found by Choudhari et al., in Aurangabad other cities in India amounting to 20.46 $\mathrm{kg} / \mathrm{m} 2$ with a standard deviation of 2.22 $\mathrm{kg} / \mathrm{m} 2 .{ }^{14}$

A total of 60 research subjects (61.9\%) have a smoking habit with a mild Brinkman index category of 55 attendants (55.7\%), while as many as 6 people $(6.2 \%)$ and there is no which is in the category of Brinkman severe index. This is in contrast to the results of research in Nigeria by Adeniyi et al., that showed gas stations that do not smoke more are 96\%. Research in Zambia also showed 176 non-smoking study subjects gas station attendant (92.6\%) while those who smoked only 14 attendants (7.4\%). The results of this different study are estimated because in most workers in Asian countries show a high prevalence of smokers. ${ }^{15}$

Gas station attendants who sampled the study had a median 
working period of 36 months with a maximum working period of 12 months and the longest of 120 months while the median duration of work in 48 hours a week. The shortest work duration in a week was found to be 40 hours and the longest 60 hours per week. Similarly, Adeniyi et al., research found gas station workers with a median working life of 30 months with a new working period of 12 months and the longest 360 months. ${ }^{12}$ Nothing yet other studies that analyze the variable duration of work within a week as done in this study.

Alam et al., in Pakistan reported research subjects with working duration categories of $<8$ hours per day, 8-12 hours per day and $>12$ hours per day. Most research subjects worked $>12$ hours per day on the study. The results showed there were significant differences in lung vital capacity (VC) between research subjects working $<8$ hours per day, 8-12 hours per day and $>12$ hours per day with $\mathrm{P}=0.029 .7 .16$ Masks as Personal Protective Equipment (PPE) on most research subjects $(97.9 \%)$ not used. Other studies have only reported that most gas station officials do not use masks during work but do not make them one of the variables in the study to be analyzed. ${ }^{10,17}$
Spirometry examination in this study uses Pneumobile Indonesia as a reference. Spirometry abnormalities were found in 42 subjects of the study consisting of 41 attendants (42.3\%) restrictions and 1 officer (1.0\%) obstruction. More than half of the study subjects showed normal spirometry results of 55 attendants (56.7\%). The results were similar to Shonga et al., studies in Zambia that reported normal pulmonary lung function in $71 \%$ of gas station attendant studied, restrictions experienced by $29 \%$ of subjects and none experienced obstruction. ${ }^{18}$ Other research by Solanki et al., in India showed restrictive abnormalities in $14 \%$ of study subjects while obstruction on only $1 \%$ of subjects. ${ }^{17} \mathrm{An}$ in vivo study in experimental mice found persistent exposure to gasoline vapor can decrease lung restriction due to reduced surfactant levels.

The Forced Vital Capacity in this study had an average of $2868.4 \mathrm{ml}$ with a standard deviation (SD) of $733.74 \mathrm{ml}$. These results are in contrast to research conducted by Kesavachandran et al., in India which found an average FVC of $3260 \mathrm{ml}$ with a SB of $670 \mathrm{ml} .^{11}$ The higher average FVC may be due to the characteristics of the subjects in the study in India as entirely male while in the study we conducted involved 25 female gas station attendants (25.8\%). 
This certainly affects the value of FVC because the lung capacity of men is greater than that of females. Average percent of FVC earned in our research is $81.6 \%$ with a default deviation of $15.06 \%$. Adeniyi et al., in Nigeria reported a similar average FVC percent of $83.4 \%$ with an SB of $12.2 \% .^{12}$

The study showed an average FEV $_{1}$ of $2597.4 \mathrm{ml} / \mathrm{s}$ with an SB of $634.99 \mathrm{ml} / \mathrm{s}$ and 84.1 percent $\mathrm{FEV}_{1}$ with an SB of $14.82 \%$. Similar results were reported in the Adeniyi et al., studies which averaged FEV $2900 \mathrm{ml} / \mathrm{s}$ with SB $700 \mathrm{ml} / \mathrm{s}$ and percent $\mathrm{FEV}_{1} 81.8 \%$ with SB $16.1 \% .^{12}$ The $\mathrm{FEV}_{1} / \mathrm{FVC}$ average in our research is $90.8 \%$ with SB $5.58 \%$. Research by Bhide et al., in India showed a similar yield of $94.56 \%$ with SB $10.09 \%$. Peak Expiratory Flow Rate of the subject of this study shows average of 6.82 liters/second with SB 1,782 liters/second is similar to Bidhe et al., 5.6 liter/s with SB 2.1 liter/s. ${ }^{19}$

The study found the majority of gas station attendants were male. This is in accordance with the research of Bhide et al., Dube et al, Solanki et al., in India whose attendants are all male and Adeniyi et al., research in Nigeria which shows $73.7 \%$ of gas station attendant are dominated by men. ${ }^{12,17,19,20}$ Proportion of male gas station attendants who have pulmonary lung function disorders more than women however is not found significant get a relationship between the gender with abnormalities in spirometry. In this study there was no significant relationship between Brinkman Index and spirometry disorder. These results are similar to Ezejindu et al., studies in Nigeria that found no relationship relationship $(P=0.514)$ between smoking habits and APE which is one of the parameters of spirometry. ${ }^{21}$

The study found the length of work within a week with a median of 48 hours in both subjects with spirometry abnormalities and normal. These length of work variables have no significant relationship with spirometry abnormalities. These results are similar to Alam et al., studies in Pakistan is analyzing the relationship between spirometry parameters and the length of work per day. The results showed there was no significant relationship between spirometry parameters are FVC, FEV 1 and APE with research subjects working $<8$ hours per day, 8 12 hours per day and $>8$ hours per day. ${ }^{16}$

In this study, there was a longer working period in the study subjects that had spirometry abnormalities, but there was no significant relationship between working time and spirometry disorder. These results are consistent 
with all three studies performed by Kesavachandran et al, Aprajita et al., and Dube et al., in India which showed that there were spirometry abnormalities in subjects with longer working period even though the studies found a significant relationship. This difference in meaning is likely due to large differences in samples and differences in length of working period. $11,20,22$

In the spirometry parameter there is a significant relationship between the working period and PEFR ( $P=0.011)$ but no significant relationship is found between the working period and the FVC parameter, \%FVC, $\mathrm{FEV}_{1}$, \%FEV ${ }_{1}$, $\mathrm{FEV}_{1} / \mathrm{FVC}$. Research by Anuja et al., in India also shows a significant relationship between working period and APE with $P=0.021$. Another study in India by Dube et al., also found that the longer the subject's working period the PEFR scores would decrease. ${ }^{20,23}$

This study subjects found who had complaints of cough or phlegm respiratory were 14 male subjects and this was more than female subjects. However, no significant relationship was found between the gender and respiratory complaints. Statistical analysis between age variables, BMI, $I B$, the use of masks, the length of work in months and working hours in a week with variable respiratory complaints also found no statistically significant relationship. Research by Zafar et al., in Pakistan found cough complaints in $80.7 \%$ of study subjects showed significant differences when compared to controls. This may be due to differences in the length of time worked and differences in the number of samples. 10

This study uses the design of cross-sectional research that has a weakness in looking at causal relationships due to the data retrieval of risk factors and effects carried out at the same time. This design is chosen based on consideration time, effort and funds available. Sampling requires the suitability of the time with the work schedule of the gas station attendant which is divided into 3 schedules namely morning, noon and night. Obstruction prevalence is only obtained on one subject so it cannot be further analyzed. Measurements of air quality performed at each gas station could not directly assess the relationship between pulmonary function disorders that occurred in the study subjects with exposure to air pollution and gasoline vapor because they were not measured Individually.

\section{CONCLUSION}

There is no significant relationship between age and pulmonary lung 
fucntion abnormalities and complaints respiratory. There is no significant relationship between gender with abnormalities of the physiology of the lungs and respiratory complaints. There is a significant relationship between the PEFR parameters and the working period of the research subject but there is no significant relationship with the other spirometry parameter.

There is no significant relationship between long working in a week with pulmonary function abnormalities and respiratory complaints. There is no significant relationship between the use of PPE when working with pulmonary function disorders and respiratory complaints. There is no significant relationship between nutritional status and pulmonary disorder and respiratory complaints. There is no significant relationship between smoking status with abnormalities of the physiology of the lungs and complaints of respiratory. Gas levels of $\mathrm{NO}_{2}, \mathrm{CO}, \mathrm{SO}_{2}, \mathrm{O}_{3}$ and $\mathrm{PM}_{2.5}$ at research site gas stations are below the threshold value.

Further research is needed in a cohort regarding the factors affecting pulmonary function in gas station attendant. In the next research, it is necessary to check surfactant levels to prove the cause of restrictions on gas station attendants.

\section{REFERENCES}

1. Badan Pusat Statistik Provinsi Jakarta Pusat dan Utara. Statistik daerah provinsi Jakarta Pusat dan Utara.

2. Marayoga T. Polusi udara di Jakarta. Harian Online Kabar Indonesia.

3. Kendaraan bermotor penyumbang polusi udara tebesar di Jakarta. http://www.greeners.co/berita/ke ndaraan-bermotorpenyumbangpolusi-udaraterbesar-di-jakarta. Accessed July 14, 2016.

4. Pencemaran udara dan sektor transportasi.

http://www.bplhdjabar.go.id/bid angpengendalian/subidpemantau anpencemaran/94. Accessed July 14, 2016.

5. Mukono H. Polusi Udara Dan Pengaruhnya Terhadap Gangguan Pernapasan. Surabaya: Airlangga University Press; 2013.

6. Begum S, Rathna M. Pulmonary function tests in petrol filling workers in Mysore city. Pak J Physiology. 2012;8(1):12-14.

7. Mukono H. Toksikologi Lingkungan. Surabaya: Airlangga University Press; 2005.

8. Hulke SM, Patil PM, Thakare AE, Vaidya YP. Lung Function Test in Petrol Pump Workers. Vol 2.; 
2012.

9. Dase $T$, Russeng SS, Muis $M$. Faktor yang berhubungan dengan kapasitas paru pada karyawan gas station pasti pas di kecamatan Tamalanrea kota Makassar tahun 2013. 2013.

10. Zafar M. Correlation of respiratory symptoms and spirometric lung pattern among petrol pump workers Karachi, Pakistan: Crosssectional survey. International Journal of Health System and Disaster Management. 2016;4(1):36. doi:10.4103/23479019.175670

11. Kesavachandran C, Rastog S, Anand M, Mathur N, Dhawan A. Lung function abnormalities among petrol-pump workers of Lucknow, North India. Current Science. 2006;90:1177-1178.

12. Bamidele A. Pulmonary Function And Symptoms Among Petrol Pump Attendants In Nigeria. Int J Biol Med Res. 2014;5:3780-3784. https://www.academia.edu/3343 9383/Pulmonary_Function_And_S ymptoms_Among_Petrol_Pump_ Attendants_In_Nigeria. Accessed December 1, 2020.

13. S. P. Choudhari SPC. Evaluation of Airway resistance and Spirometry in Petrol Pump Workers: A Crossectional study. IOSR Journal of Dental and Medical Sciences. 2013;5(2):69-71.

doi:10.9790/0853-0526971

14. World Health Organization (WHO). Tobacco Questions for Surveys: A Subset of Key Question from the Global Adult Tobacco Survey (GATS). 2nd ed. Atlanta: WHO; 2011.

15. Hamzah NA, Mohd Tamrin SB, Ismail NH. Metal dust exposure and lung function deterioration among steel workers: an exposure-response relationship. International Journal of Occupational and Environmental Health. 2016;22(3):224-232. doi:10.1080/10773525.2016.120 7040

16. Alam R, Zafar A, Ghafoor A, Naseem A, Ali $Q$, Imtiaz F. Lung function abnormalities among fuel filling workers in Karachi, Pakistan. Pinnacle environmental \& earth sciences. 2014;1(1):183187.

17. Solanki RB, Bhise AR, Jadav JC. Prevalence Of Lung Function Abnormalities In Petrol Filling Workers, IJSR - International Journal of Scientific Research(IJSR), IJSR | World Wide Journals. International Journal of Scientific Research. 2014;3(9):372-374. 
https://www.worldwidejournals.c om/international-journal-ofscientific-research(IJSR)/article/prevalence-of-lungfunction-abnormalities-in-petrolfilling-workers/Mzk5MA==/?is=1. Accessed December 1, 2020.

18. Shonga T, Siziya S. Association between exposure to fuel and respiratory health among fuel attendants in Ndola, Zambia. Asian Pacific Journal of Health Sciences. 2015;2(4):27-32. doi:10.21276/apjhs.2015.2.4.7

19. Bhide $A$, Munisekhar $K$, Hemalatha D, Krishna Gouroju S. Access this Article online. International Journal of Physiotherapy and Research. 2014;2(1):354-358. www.ijmhr.org/ijpr.html.

Accessed December 1, 2020.

20. Dube S, U MS, Kulkarni M, Professor A. Evaluation of Respiratory Functions in Petrol Pump Workers at Nanded. Vol 8. Statperson Publications; 2013.

21. Dn E, Joseph E U, Happy I. The Peak Expiratory Flow Rates of Petrol Station Attendants in Nnewi Using a Wright Peak Flow Meter. 2014;2(3):231-235. www.pharmahealthsciences.net. Accessed December 1, 2020.

22. Le Mesurier SM, Stewart BW, O'connell PJ, Lykke AWJ.
Pulmonary responses to atmospheric pollutants. II. Effect of petrol vapour inhalation on secretion of pulmonary surfactant. Pathology. 1979;11(1):81-87. doi:10.3109/00313027909063542

23. Anuja A V, Veeraiah $V$, Johnson $P$, Subashini AS. Evaluation and comparison of pulmonary function tests in petrol pump workers Vs individu-als unexposed to petrol fumes. $J$ Clin Biomed Sci. 2014;4(2):276-281. www.jcbsonline.ac.in. Accessed December 1, 2020. 